\title{
ENGLINGHTNING THE HOLISTIC CONCEPT OF BAHAQ-E-ABYAZIN UNANI SYSTEM OF MEDICINE: REVIEW OF LITERATURE.
}

\author{
Dr. Rafiya Riyaz Ahmed ${ }^{1}$, Dr. Ahmad Mahfoozur Rahman², \\ Dr. Asif Ansari ${ }^{3}$, and Dr. A.H. Farooqui ${ }^{4}$. \\ ${ }^{1}$ PG Scholar Department of Moalijat \\ ${ }^{2}$ Assistant Professor Department of Moalijat \\ ${ }^{3}$ Assistant Professor Department of Ilmul Advia \\ ${ }^{4}$ Principal and HOD Moalijat \\ ZVM Unani Medical College and Hospital, Pune, Maharashtra
}

Review Paper

Received: 15.11.2021

Revised: 25.11.2021

Accepted: 10.12.2021

\begin{abstract}
The study of skin, the science of dermatology, has undergone significant transformations throughout the centuries. From the first descriptions of skin diseases in Egyptian papyri and in Hippocratic writings to the first treatises on dermatology, important individuals and discoveries have marked the specialty. A comprehensive description of Amrazejild (skin diseases) is available in classical Unani literature. Ancient Greco-Arabic scholars have described Bahaq-e-Abyaz (pityriasis) in detail along with etiopathogenesis, clinical features, complications, and management in their treatises. Ancient Unani scholars have been treating Bahaq-e-Abyaz successfully since antiquity. They have mentioned and practiced a compendium of single as well as compound herbo-mineral formulations for the treatment of Bahaq-e-Abyaz. It is important to provide a historical synthesis for the medical community to recognize and understand the holistic concept of Bahaq-e-Abyaz along with the treatment as mentioned in classics of Unani medicine.
\end{abstract}

No. of Pages: 3

References: 23

Keywords: Amrazejild, Bahaq-e-Abyaz, Greco-Arabic.

\section{INTRODUCTION}

In the Unani system of medicine, Hippocrates (460-370 BC), founded the concept of four humor forms the basis of health and disease. ${ }^{[1][2]}$ The basic etiology of Bahaq-e-Abyaz is derangement in quality or quantity of Balgham inside the body ${ }^{[2]}$.

Ibn Sina (980-1037A.D.) the author of "Al Qanoon Fil Tib" an encyclopedia of medicine, served as a standard text book of medicine in Europe till $17^{\text {th }}$ century A.D. extensively described the etiopathogenesis, types, clinical presentation and treatment of Bahaq. He described that Bahaq-e-Abyazis the hypo pigmentation and Bahaq-e-Abyaz is the hyperpigmentation of skin occurring superficially as a result of weakness of quwat e mughaiyarah of $\operatorname{skin}^{[3]}$. M H Qamari (9th Century A.D.) quoted in "Ghina Muna" that Bahaq-eAbyaz is a type of humoural disease occurring due to alteration in the quality and quantity of Balgham. ${ }^{[4]}$

Majoosi (930-999 A.D.) discussed Bahaq-e-Abyaz, its

*Corresponding author: momin_rafiya@yahoo.com 
aetiology, clinical presentation and treatment in his treatise "Kamilus Sanah". According to him Bahaq-e-Abyaz is a superficial and mild hypopigmentation of skin. It is small, round in shape and appears suddenly ${ }^{[5]}$. Najeebuddin Samarqandi an eminent unani scholars of 13th century A.D described the aetiology, clinical features, treatment and prophylactic measures of both Bahaq and Bars in detail in his treatise "Al Asbab wa Al Alamaat". ${ }^{[6]}$

\section{ETIOPATHOGENESIS}

According to the Unani doctrine, Bahaq is a humoural disease occurring dueto the alteration in the quality and quantity of either Balgham (phlegm) or Sauda (blackbile). Excessiveaccumulationofabnormalphlegmresultinwhitedis colouration of skin (Bahaq-e-Abyaz) while the excess accumulation of morbid blackbile leads to blackdis colouration of skin (Bahaq-e-Aswad). [4][7][8][9] $^{[}$

Raban Tabri, a legendary Unani Physician and author of his famous book "Firdausul Hikmat" says that the actual pathogenesis of Bahaq is attributed to Fasade dam (blood impairment) and Buroodat dam (coldness of blood). If the blood impairment occurs due to Sauda, then Bahaq-e-Aswad is produced and if blood impairment is due to Balgham, Bahaq-eAbyaz or Barsis produced. He further says that if blood impairment is due to Ghaleez Ratoobat (thick humours) and Hiddatedam (abnormal heat in blood), then Kharish (pruritus) develops and if the cause of blood impairment is Buroodat wa Ghilzate dam (coldness and thickness of blood), then Qooba (Dermatophytosis) results. ${ }^{[10]}$

Ibn Zohar (11 ${ }^{\text {th }}$ century A.D), a well known Unani Scholar and author of "Kitabul Taisir" described that Bahaq-eAbyazis a metabolic disease occurring due to Zoafe Hazm of organs while Bahaq-e-Aswadis a black patch on skin caused due to the accumulation of melancholic humour. ${ }^{[9]}$

Ibn Rushd (12 $2^{\text {th }}$ century A.D.) stated that Bahaq usually occurs due to weakness of Quwate Mumayyeza of liver or malabsorption of sauda in spleen or due to Suemizaj (derangement of temperament) of vessels that result in excess production of sauda inside the body ${ }^{[11]}$. Some authors suggested that Bahaq-e-Abyaz may also occur due to personal unhygienic conditions, use of dirty and untidy garments, and intake of heavy and flatulent food items. ${ }^{[12][13]}$

\section{CLASSIFICATION}

Depending upon the nature of causative humour involved, Bahaq is classified in to two types viz; $;^{[3][4][5][13]}$.

1. Bahaq-e-Abyaz commonly name das Cheep is hypopigmentation of skin occurring due to the accumulation of morbidphlegm in the body.
2. Bahaq-e-Aswad is hyper pigmentation of skin caused due to the excess accumulation of black bile in the body.

\section{CLINICAL PRESENTATION}

The typical clinical features of Bahaq-e-Abyaz as described by Unani scholars are hypopigmentation, scaling of skin associated with or with out itching. Bahaq-e-Abyaz is a superficial mild hypo pigmentation of skin. ${ }^{[15][4][9][16][17]}$ It is small round in shape and appears suddenly. According to Hakeem Ajmal Khan, Bahaq-e-Abyaz is a whiteness characterized by scaling and itching appearing mostly on trunk (chest and abdomen), cheeks andarms. Initially small white yellow spots appear which coalesce together to form a big depigmented patch. These white patches are slightly raised from the surface of skin but too difficult to be differentiated. ${ }^{[12][13][21]}$

Mohammad Tabri in his famous book, Moalejate Buqratia, mentioned that Bahaq and Bars are differentiated from each other on the basis of shape and form of lesions. The lesion of Bahaq is round, remains localized and does not spread. There is no scaling and skin colour is slightly different from the normal colour, whereas the lesion of Bars is shiny, smooth and soft to touch and spreading in nature. ${ }^{[7][17]}$

Akbar Arzani distinguished Bahaq-e-Abyaz from Bars by stating that Bahaq-e-Abyaz remains superficial and does not penetrate deep into the skin. After pricking the needle at the site of Bahaq, blood always comes out and the growing hairs at the site of lesion never turns white even after the chroni city of disease. But the whiteness of Bars penetrates deep into the skin and the growing hairs at the site of lesion are always white. ${ }^{[3[15][16]}$ The authors of Moalejate Nafeesi, Aqsarai and Sadeedi unanimously mentioned that both Bahaq as well as Bars are skin diseases characterized by white patches in which former remains superficial and does not penetrate deep while later penetrates deep in to the skin and muscles. ${ }^{[18][19][20]}$

Bahaq-e-Abyaz and Bahaq-e-Aswad differ from each other on the basis of their clinical manifestations. Bahaq-e-Aswad occurs mostly in adolescence an discharacterized by the formation of scales in skin just like scales of wheat shell. ${ }^{[15][17][19]}$ It occurs in those people who are obese with prominent vessels and profuse hairs. According to Razi, It is characterized by jamood (stagnation) in skin. ${ }^{[8]}$ While Kabirruddin described Bahaq-e-Aswad as black discolouration of body with irritation, burning and scaling of skin. $^{[22]}$

The area of Bahaq-e-Abyaz becomes red on rubbing. Bahaqe-Aswad resembles Qooba in its clinical presentation; just like Qooba, the lesion of Bahaq-e-Aswad is hard and causes itching and peeling or scaling of skin similar to the scales of 
fish. Further Bahaq-e-Aswad is easily differentiated from Bars Aswad as the lesion of Bahaq-e-Aswad is soft while that of Bars Aswad is hard. The diagnosis of Bahaq-e-Abyaz is more difficult than Bahaq-e-Aswad. If Bahaq is spreading over large area of body, it is difficult to be cured. ${ }^{[3][14]}$

\section{TREATMENT:}

Unani system of medicine offers a quite effective treatment of Bahaq-e-Abyaz, which is totally based on the holistic approach. Unani scholar described Bahaq wa Bars together. Thus, as described by Greco Arabic physicians like Ibn Sina, Razi, and Ismail Jurjani in their treatises, the overall management is based on three therapeutic modalities as follows $^{[3-5][8][14][15]}$ :

\section{(1) Ilaj Nafsani (Psyco-therapy).}

(2) Ilaj Bil Ghiza (Dieto-therapy).

(3) Ilaj Bil Dawa (pharmaco-therapy).

\section{(1) Ilaj Nafsani (Psyco-therapy)}

Bahaq-e-Abyaz and Bars both are associated with social stigma because of cosmetic problems. Usually the patients are depressed psychologically because there is myth in the society that both the diseases are communicable just like Jarb (scabies) and Juzam (leprosy). Therefore, psychological counselling or psychotherapy is the foremost and indispensable part of treatment. The patient and their relatives should be assured first to get rid of their misconception about the disease and its prognosis. Most of the patients are curious about the disease and depressed psychologically. Therefore the psychological care of the patient is essential and it is a part of therapy.

\section{(2) Ilaj Bil Ghiza (Dieto-therapy)}

Unani physicians suggested that such diets should be given thatare easily digestible, produce sufficient pure blood and that have har mizaj. They have recommended the meat of birds and goats in diet. Further, they have stated that the diet should be taken only when it is desired and also advised the intake of digestive tonics 2 hours after meals to accelerate the processes of digestion and absorption. Unani scholars have advised the patients to avoid the intake of such food items that lead to the increased production of phlegm and black bile that are the actual culprits for the genesis of disease. According to Ibn Sarabiyoon, ${ }^{[1][23]}$, patients are advised to avoid cold and moist dietary items such as fresh fish, fresh vegetables, fruits, and fatty diet.

\section{(3) Ilaj Bil Dawa (Pharmacotherapy)}

It is performed by applying the following steps (Usool):

\section{UsooleIlaj and Ilaj of Bahaq-e-Abyaz:}

- Istifraghor Tanqiya Balgham (Ellimination of Phlegm)

- Tadeel Mizaj (Restoration of normal Temperament)

- Islahe Hazm (Correction of digestion)

- Topical application of Jali, Muhamir and Musakhkhin advia in the form of Tila, Zimad and Roghan (Jelly, ointmentoroil).

\section{Istifraghor Tanqiya Balgham}

Bahaq-e-Abyaz is a chronic disease caused by the excessive accumulation of morbid phlegm. Ancient Unani physicians have suggested that its treatment should begin with the evacuation of excess phlegm from the body through various means. The commonest mode of Istifragh employed for the excretion of phlegm is usually done in three steps;

\section{Use of Munzijate Balgham (Phlegmatic Concoctives) \\ 2. Use of Mushilate Balgham (Phlegmatic Purgatives) \\ 3. Tabreed Badan}

\section{Munzijate Balgham}

Bekhe badiyan 7gm, Bekhe kasni 7gm, Bekhe karafs 7gm, Bekhe kibr 7gm, Bekhe izkhar 7gm, Asalassoos muqashar $7 \mathrm{gm}$, Barge gauzuban 7gm, Anjeer zard 5 No., Maweez munaqa 8 No., Gulqand asli $15 \mathrm{gm}$.

Patients are advised to take $40 \mathrm{ml}$ decoction on empty stomach twice a day for a period of 2-3 weeks till the symptoms of Nuzj appears. Then, an appropriate dose of Mushilate Balgham is added to the decoction of Munzije Balgham for a period of 3-5 days to induce purgation.

\section{Mushilate Balgham}

Barge sana 6gm, Turbud 6gm, Turanjabeen 48gm, Ghariqoon 4gm, Maghzamaltas 48gm, Sheerekhisht 7gm, Roghanebaed anjeer $25 \mathrm{ml}$.

\section{Tabreed}

This is usually done with the help of Mubarridat to neutralize the side effects of Mushilaton intestines. Commonly used drugs are Lu'abebahidana, Lu'abe ispagol, Lu'abe resha khatmi, Sheera unnab, Sheera badiyan, Arqe shahitra etc. These are used for a period of 2-3 days.

After the completion of Munzij wa Mushil therapy, patients are advised totake hot Ma'ajeen, Harirajat and Itrefalat. Then the specific drugs of Bahaq-e-Abyaz are advised for topical application.

\section{Topical Therapy}

Drugs having properties like Jali, Muhammir. Muhallil and Musakhkhin are used locally in the form of Tila, Zimad and 
Roghan (Jelly, ointmentor oil). Commonly used herbomineral drugs employed for topical application in Bahaq are Sirka, Gandhak, Qust, Sheetraj Hindi, Filfil, Zarneekh ahmar, Zangar, Zaje akhzar, Majeeth, Tukhme turb, Kundush, Kharbaq, Shuneez, Zarareeh, Zarnab, Khardal, Natroon, Unsul, Lehsun etc. After the topical application of drugs the affected area is exposed to sunlight for about 5-10 minutes that enhances the process of repigmentation.

Zakaria Razi ${ }^{[8]}$, an eminent Unani scholar has suggested several means of topical regimens that are beneficial for the ailment. These include continuous Takmeed (fomentation) of affected area with hot water until it becomes hot followed by application of emollient drugs, multiple pricking with needle at the site of lesion and exposure of affected area to sunlight.

\section{PROGNOSIS}

According to Ahmad bin Rabban Tabri, ${ }^{[7]}$ the usual response of the treatment varies from person to person. It depends on duration, site of lesion, size, and type of lesion. The factors supposed to be responsible for the failure of treatment are presence of patches on hands, feet, front of wrists, above the iliac crest, waist, and lips; presence of white hairs on patches; poor nutritional state; presence of helminthic infestation, stress, anxiety, emotional upsets, old age, indigestion, heredity, and constipation.

\section{CONCLUSION}

It may be concluded that Bahaq-e-Abyaz is chronic humoral disease occurring because of alteration in the quality and quantity of morbid phlegm beneath the skin and resulting in hypopigmented patches. Under the influence of the accumulation of morbid humors beneath the skin, the normal physiology of skin gets altered and its protective mechanism is lost; consequently it becomes susceptible to infections. Despite the use of numerous newer therapeutic regimens, in Western medicine, Bahaq-e-Abyaz have remained an enigma because of recurrence and resistance of the antibiotics. Greco-Arab medicine axiomatically claims for successfully treating these diseases since a long time without any unwanted effects. The treatment is based on the holistic approach of Munzijwa Mushil therapy along with the topical application of Jali, Muhammir, Muhallil, and Musakhkhin drugs. Thus, Unani medicine is preferred over contemporary medicine in the treatment of these refractory skin ailments.

\section{REFERENCES}

1. A. Shabnam, K. Qamar Alam, Ruby Anjum et al. Fundamentals of Unani System of Medicine - A Review. European Journal of Biomedical AND Pharmaceutical Sciences 2017.4(9):pg no.219-223. Available from www.researchgate.net/publication/321386220_FUND AMENTALS_OF_UNANI_SYSTEM_OF_MEDICIN E-A_REVIEW.
2. H. Azad, A. Tanzeel., Anwar. M [et al]. Holistic Concept of Bahaq Wa Bars And Their Management In Unani (Greco-Arab) System of Medicine. Medical Journal Of Islamic World Academy of Science 2012. 20(4):pg no 113-120 available from https:// www.journalagent.com/ias/pdfs/IAS_20_4_113_120.p df.

3. Hkm Ibne Sina:Al Qanoon Fit Tib ;New Delhi: Idara Kitab Us Shifa; June 2010. pg no.1424.

4. Hkm Qamri A.H.M. Gina Muna ;New Delhi :CCRUM. 2008 pg no 452-453.

5. Hkm Abbas Majusi. Kamilus Sanah .New Delhi:Idara Kitabus Shifa. Jan 2010 :pg no.245-247.

6. Hkm Nafis. Kirmani Sharah Asbab;New Delhi:2014ejaz Publication House :pg no342-343.

7. HkmAbul Hasan Ahmed Bin Mohd Tabri. Molejate Bukratiya; New Delhi: 1997. Central Council For Research in Unani Medicine(CCRUM): pg no.195-197.

8. HkmRazi AMBZ. Alhavi Fit Tib. Vol-23 (Urdu translation by Hakeem M Y Siddiqui) AMU: Sabba Publishers Aligarh; 1994: pg no.17-27.

9. HkmIbne Zohar. Kitab al Taisir Fil Mudawat wat Tadbir. $1^{\text {st }}$ ed. (Urdu translation byCCRUM). New Delhi: MinistryofHealthandFamilyWelfare;1986:pg no.201202.

10. HkmRabban Tabri. Firdousul Hikmat; Deoband: Faisal Publication .2002:pg no 294-297.

11. HkmIbne Rushid. Kitab al Kulliyat. $2^{\text {nd }}$ ed. (Urdu translation by CCRUM). New Delhi: Ministry of Health and Family Welfare; 1987: pg no.109-110, 291, 299, 305.

12. Hkm Gulam Jillani. Makhzanul Hikmat; New Delhi: Ejaz Publication House. 2010:pg no1033.

13. Hkm Gulam Jillani. Makhzanul Ilaj; New Dehli Idara kitabus Shifa. Sep 2005: pg no.724-726.

14. Hkm Ismail Jurjani. Zakhera Khawarzamshahi.New Delhi; Idara Kitabus Shifa;jan 2010:pg no.18-21.

15. Hkm Akbar Arzani. Tibbe Akbar. Deoband;Faisal Publication:pg.no.732-733.

16. Hkm Qurrah SI. Tarjumae Zakheera Sabit Ibne Qurrah. (Urdu translation by Hakeem S A Ali) AMU: Litho Colour Printers Aligarh; 1987:pg no 359-360.

17. Hkm Akbar Arzani. Mizanut Tib. New Delhi: Idara Kitabush Shifa; 2002:pg no.254.

18. Hkm Nafees. Moalejat Nafeesi (Arabic). Luckhnow: Matba Munshi Naval Kishore;1324Hijri: pg no.531532. 
19. Hkm Jamaluddin A. Aqsarae (Arabic) Vol-3. Luckhnow: Matba Munshi Naval Kishore; YNM: 476477, 790 .

20. Hkm Gajrooni. Al Sadeedi (Arabic). Luckhnow: Matba Naval Kishore; 1311 Hijri: pg no.61-62.

21.Hkm Ajmal Khan. Hazi;.Dehli.Hindustani Dawakhana.1987.pg no.385-86.
22. Hkm Kabiruddin. Bayaze Kabeer. New Delhi: Idara Kitabus Shifa. jan2010.pg no.240.

23. Hkm Khalid G. Amraze Jild aur Ilaje Nabwi (saw). Delhi: Adabi Duniya, 1993: pg no. 113-16. 